Article

\title{
Applications of Satellite-Based Rainfall Estimates in Flood Inundation Modeling-A Case Study in Mundeni Aru River Basin, Sri Lanka
}

\author{
Shuhei Yoshimoto and Giriraj Amarnath * \\ International Water Management Institute (IWMI), Battaramulla 10120, Sri Lanka; s.yoshimoto@cgiar.org \\ * Correspondence: a.giriraj@cgiar.org; Tel.: +94-11-288-0000
}

Received: 19 July 2017; Accepted: 22 September 2017; Published: 27 September 2017

\begin{abstract}
The performance of Satellite Rainfall Estimate (SRE) products applied to flood inundation modelling was tested for the Mundeni Aru River Basin in eastern Sri Lanka. Three SREs (PERSIANN, TRMM, and GSMaP) were tested, with the Rainfall-Runoff-Inundation (RRI) model used as the flood inundation model. All the SREs were found to be suitable for applying to the RRI model. The simulations created by applying the SREs were generally accurate, although there were some discrepancies in discharge due to differing precipitation volumes. The volumes of precipitation of the SREs tended to be smaller than those of the gauged data, but using a scale factor to correct this improved the simulations. In particular, the SRE, i.e., the GSMaP yielding the best simulation that correlated most closely with the flood inundation extent from the satellite data, was considered the most appropriate to apply to the model calculation. The application procedures and suggestions shown in this study could help authorities to make better-informed decisions when giving early flood warnings and making rapid flood forecasts, especially in areas where in-situ observations are limited.
\end{abstract}

Keywords: satellite rainfall observation; flood monitoring; flood inundation simulation; rainfall runoff model

\section{Introduction}

Experts consider that extreme weather events associated with climate change are becoming more severe worldwide. Water-related disasters, such as floods and droughts, are expected to increase. People in poverty in developing countries are particularly likely to be exposed to extreme weather events. According to the International Disaster Database of the Center for Research on the Epidemiology of Disasters (EM-DAT; [1]), about 3 billion people globally were affected by floods and droughts between 1995 and 2014. There is concern that human livelihoods and food production will increasingly be affected by water-related disasters as climate change progresses.

Remote sensing techniques, including satellite image analysis, have been employed to capture the extent of areas affected by water-related disasters. However, there are limitations to such methods; for example, satellite images are not always available due to the satellite's orbital period or cloud cover. Recently, several authors have suggested applying rainfall estimates derived from remote sensing to hydrological numerical models to simulate the flood inundation extent.

Satellite Rainfall Estimate (SRE) products provide global-scale spatial data on rainfall intensity. Among them are: Precipitation Estimation from Remotely Sensed Information Using Artificial Neural Networks (PERSIANN [2]); the Tropical Rainfall Measuring Mission (TRMM [3]); and the Global Satellite Mapping of Precipitation (GSMaP [4]). These datasets have been applied to numerical hydrological models to simulate floods in various locations of the world [5-8]. Within South Asia, Nanda et al. [9] used an SRE dataset to develop a real-time flood-forecasting model for a basin in eastern India. 
Numerical hydrological models, such as LISFLOOD-FP [10], HEC-HMS/RAS [11,12] and the RRI (Rainfall-Runoff-Inundation) model [13], have been developed and used to simulate flood inundation. Of these, the RRI model has advantages that include: the ability to simultaneously calculate flood inundation and river flow in areas encompassing downstream flood plains and upstream mountain zones; the facility to make calculations for multiple basins in cases where the downstream floodplain can be affected by several rivers; and free availability, making it more accessible to developing countries.

There have been several studies to apply SREs to the numerical hydrological models. Some employed multiple SREs and then tested their validity by comparing stream discharge [5,14-18]. Flood inundation extent and depth have also been simulated by applying solo SREs such as PERSIANN and TRMM to distributional flood models $[8,19]$. In addition, the RRI model has been utilized with GSMaP to simulate the 2008 flood event in Pakistan [20]. In the meantime, SRE products have been compared with each other and their characteristics and accuracy have also been evaluated [21-23]. However, evaluation among multiple SREs in terms of flood inundation reproducibility has not been done yet. It would be important to evaluate the applicability of SREs to flood inundation simulation, because the quality of rainfall information plays a key role in flood simulation, especially in less-gauged areas which have few observation stations of ground-level rainfall and stream discharge, where most of the developing regions are situated.

The authors previously demonstrated that it is possible to apply SREs to the RRI model to simulate basin-scale flood inundation [24]. This indicated that applying SREs to the RRI model could support the provision of early flood warnings, even in basins with few or no rainfall gauges. However, the model could potentially accept a variety of SREs, some of which might perform better than others. This paper illustrates the procedures to test the performance of PERSIANN, TRMM, and GSMaP in the RRI model for simulating flood inundation extents.

\section{Materials and Methods}

\subsection{Study Area}

The study area, encompassing the Mundeni Aru River Basin (hereafter, MRB), is located in eastern Sri Lanka (Figure 1). The catchment area of the MRB is approximately $1300 \mathrm{~km}^{2}$, with the highest point standing $873 \mathrm{~m}$ above sea level. A large part of the catchment area is covered by mostly forest and paddy fields. A dam with storage of $59.2 \times 10^{6} \mathrm{~m}^{3}$ began operating in the upstream part of the MRB in July 2013 [25].

According to EM-DAT [1], nine major riverine flood events occurred in Sri Lanka between 2011 and 2015, together causing more than 300 deaths. Heavy rains at the beginning of 2011 seriously affected residents and agricultural production across parts of northeastern Sri Lanka. In the MRB, a major flood event on 3 February 2011 induced broad-spread inundation, mostly in the downstream part of the basin, with the water depth reaching approximately $2 \mathrm{~m}$ (Figure 2; [26]). A further flood affected eastern Sri Lanka in December 2012.

River discharge in the MRB was observed at a gauging station in Tampitiya, and rainfall was measured at stations in Rugam, Kolaneyaya, and Kongaspenvila (Figure 1) by Sri Lanka's Department of Irrigation. Discharge was recorded several times a day; for this study, these data were averaged into daily values. Rainfall was measured daily. Data for both were available from 1 October 2010 to 30 September 2014. 


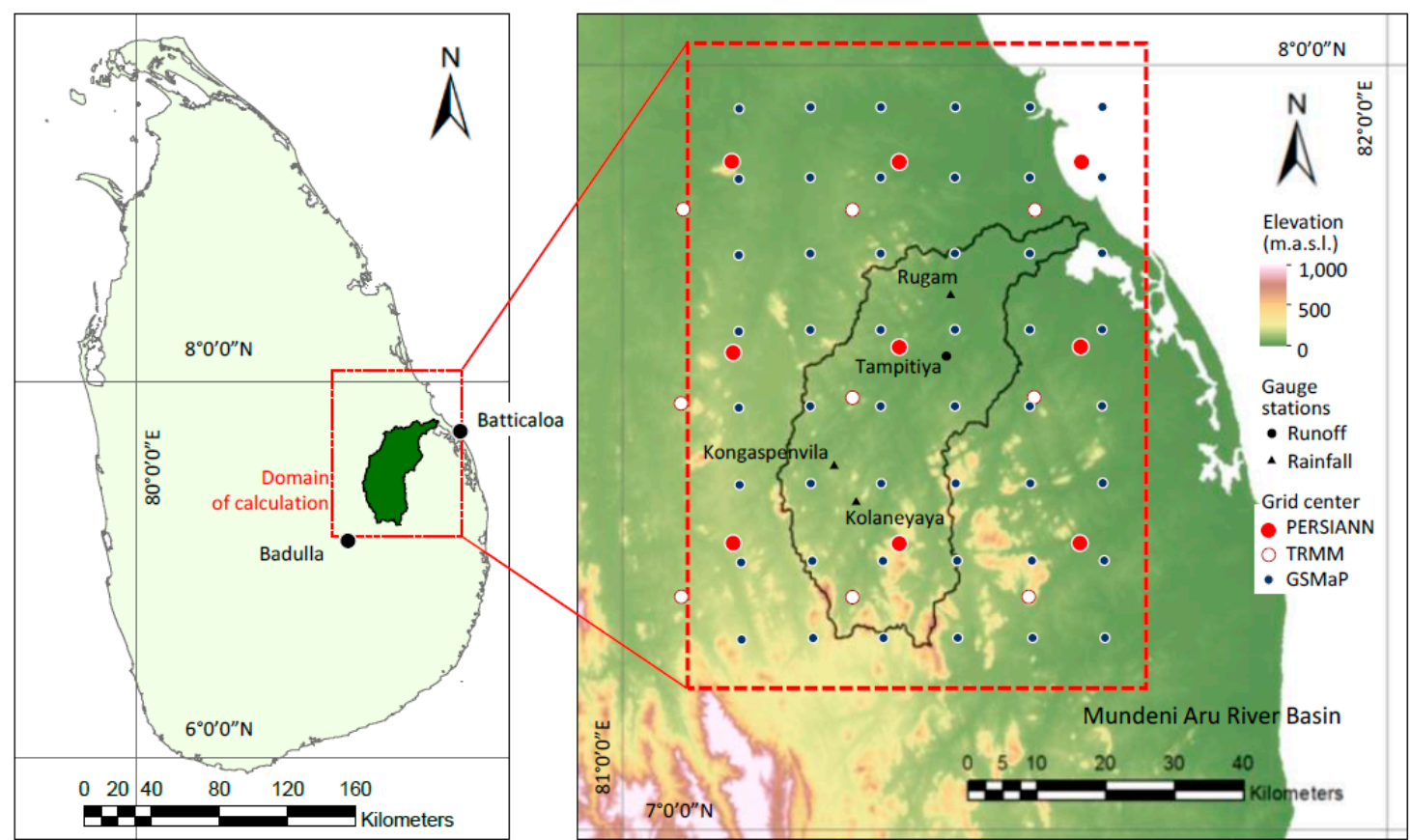

Figure 1. Domain of the calculation of the study area showing gridded points of the Satellite Rainfall Estimates (SREs) and gauge stations for runoff and rainfall.

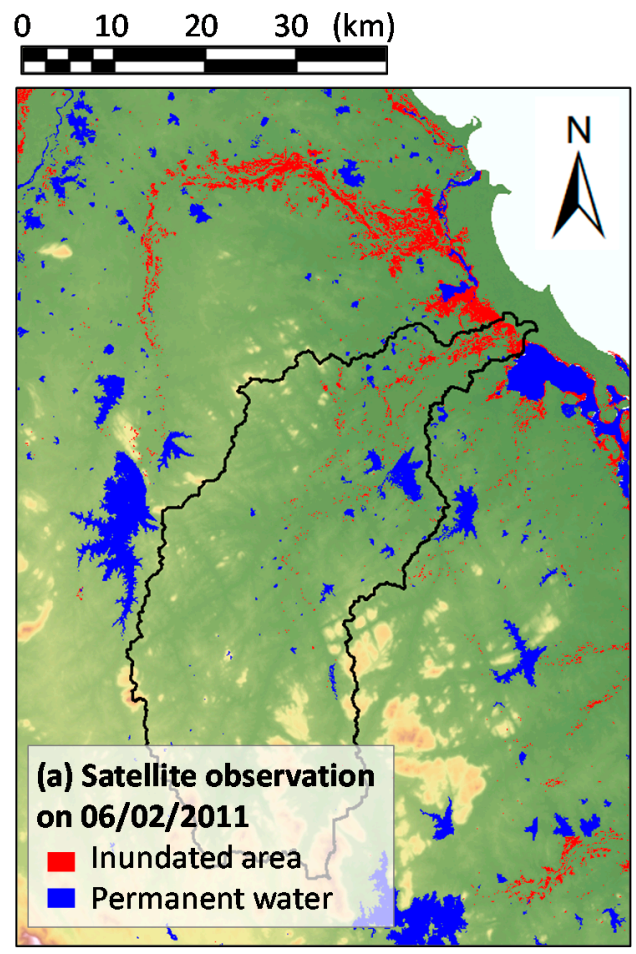

Figure 2. Inundation extent of a flood in January and February 2011, analyzed by satellite observation images [26].

\subsection{Satellite Rainfall Estimate Products}

PERSIANN, TRMM, and GSMaP SREs were tested. Their specifications are written in Table 1. The PERSIANN system uses neural network function procedures to compute an estimate of rainfall rate from the observation data of multiple satellite infrared sensors, and the products are calibrated 
with rainfall estimates by satellite microwave observations [27]. TRMM is a project aimed to provide precipitation information for tropical and sub-tropical regions and also a name of satellite launched by the National Aeronautics and Space Administration (NASA) that comprises microwave-, infrared- and visible-wavelength sensors [28]. In this study, TRMM 3B42 V7 dataset was used, which incorporates microwave and infrared data from multiple satellites including TRMM. GSMaP is a platform hosted by the Japan Aerospace Exploration Agency (JAXA) to provide near-real-time and reanalyzed global dataset based on microwave and infrared satellite data combined using a Kalman filter. The period for which data was available and its resolution, for both gauged rainfall (hereafter Gauged-R) and the SREs, is also shown in Table 1.

Data in nine cells of the PERSIANN and TRMM SREs, correlating to the study area, were selected and then applied to the model (Figure 1). Similarly, the data in 48 cells of the GSMaP product were selected and applied to the model.

Table 1. Satellite rainfall estimates data description and its salient features.

\begin{tabular}{|c|c|c|c|c|}
\hline Dataset/Version & Resolution & Base Data and Estimation Method & Mission Cycle & Data Period \\
\hline Gauged-R & (3 stations) & Ground observation & Real time & $\begin{array}{l}1 \text { October } 2010 \text { to } \\
30 \text { September } 2014\end{array}$ \\
\hline PERSIANN & 0.25 degree & $\begin{array}{l}\text { Multiple satellite infrared data, combined } \\
\text { by applying neural network algorithms, } \\
\text { and calibrated by satellite microwave } \\
\text { rainfall products }\end{array}$ & Operational & $\begin{array}{l}1 \text { January } 1983 \text { to } \\
\text { 30 December } 2014\end{array}$ \\
\hline TRMM (3B42 V7) & 0.25 degree & $\begin{array}{l}\text { Microwave and infrared data from } \\
\text { multiple satellites, with gauge adjustment }\end{array}$ & Completed & $\begin{array}{c}1 \text { January } 1998 \text { to } \\
30 \text { December } 2014, \\
\text { but not available in } \\
\text { November and } \\
\text { December in } 2013\end{array}$ \\
\hline $\begin{array}{c}\text { GSMaP } \\
\text { (V6 reanalysis) }\end{array}$ & 0.10 degree & $\begin{array}{l}\text { Passive microwave and infrared data, } \\
\text { combined using a Kalman filter. The } \\
\text { reanalysis version is gauge-adjusted }\end{array}$ & Operational & $\begin{array}{l}1 \text { January } 2001 \text { to } \\
28 \text { February } 2014\end{array}$ \\
\hline
\end{tabular}

\subsection{The RRI Model}

The RRI model [13] was employed to calculate flood inundation extent and depth for heavy rainfall events pertinent to this study. The model is a two-dimensional raster-based model which considers water movement in both slopes and river channels. The governing equations of lateral flow on slopes considered in the model are composed of the following mass balance Equation (1) and momentum Equations (2) and (3):

$$
\begin{gathered}
\frac{\partial h}{\partial t}+\frac{\partial q_{x}}{\partial x}+\frac{\partial q_{y}}{\partial y}=r \\
\frac{\partial q_{x}}{\partial t}+\frac{\partial u q_{x}}{\partial x}+\frac{\partial v q_{x}}{\partial y}=-g h \frac{\partial H}{\partial x}-\frac{\tau_{x}}{\rho_{w}} \\
\frac{\partial q_{y}}{\partial t}+\frac{\partial u q_{y}}{\partial x}+\frac{\partial v q_{y}}{\partial y}=-g h \frac{\partial H}{\partial y}-\frac{\tau_{y}}{\rho_{w}}
\end{gathered}
$$

where suffixes $x$ and $y$ indicate directions in the $x$-y coordinate system, $h$ is height of water from the local surface, $q_{x}$ and $q_{y}$ are the unit width discharges, $u$ and $v$ are flow velocities, $r$ is rainfall intensity, $H$ is height of water from the datum, $\rho_{w}$ is the density of water, $g$ is the gravitational acceleration, $\tau_{x}$ and $\tau_{y}$ are shear stresses, and $t$ is time. The spatial differentiation in the momentum Equations (2) and (3) are converted to functions of $H$ by applying Manning's law. The model can also consider percolation and groundwater flow governed by Darcy's law. Then, the spatial differentiation in the mass balance Equation (1) is discretized by the first-order finite difference method, and the time differentiation is resolved by the fifth-order Runge-Kutta formula. Details in the differentiation and surface-subsurface water interactions are described in the RRI model manual [13]. 
The model calculation requires rasterized topographic information as well as distributional rainfall input. In this study, HydroSHEDS with 30-second (approximately 900-m) resolution, provided by U.S. Geological Survey [29], was applied.

The RRI model requires the operator to set parameters for the calculation. The parameters are listed in Table 2. In this study, the degree of freedom of the model parameters was reduced in the following ways: (1) Values of the parameters related to the cross-sectional shape of channels and soil capacity were fixed to the default values shown in the manual [13], since dimensions of the rivers had not been measured on site. It was confirmed that river width calculated with the default parameters was mostly equal to that roughly measured in aerial photographs; (2) Every cell was considered to have a channel (a reasonable assumption given the prevalence of drainage canals on farmland in rural areas). Under these conditions, the parameters that have to be calibrated could be limited to Manning's roughness and groundwater permeability. Calibration was carried out using gauged rainfall data for the period from 1 January to 28 February 2011 by comparing hydrograph and inundation extent. Procedures were according to the authors' previous study [24].

Table 2. List of parameters of the Rainfall-Runoff-Inundation (RRI) model used in this study.

\begin{tabular}{|c|c|c|c|}
\hline & Explanation & Value & How to Determine the Parameter Values \\
\hline$n_{\mathrm{S}}$ & Manning $n$ for slope & 0.06 & \multirow{3}{*}{ Determined by calibration } \\
\hline$n_{\mathrm{R}}$ & Manning $n$ for channel & 0.03 & \\
\hline$k_{\mathrm{a}}$ & Permeability for groundwater flow & 0.1 & \\
\hline$d_{\mathrm{a}}$ & Capacity of soil & 1.0 & \multirow{5}{*}{ Default values shown in the manual } \\
\hline$C_{\mathrm{w}}$ & Parameters for cross-sectional shape of & 5.0 & \\
\hline$S_{\mathrm{W}}$ & channel $(\mathrm{m})$ : & 0.35 & \\
\hline$C_{\mathrm{d}}$ & Width $=C_{\mathrm{w}} A^{S \mathrm{w}} ;$ Depth $=C_{\mathrm{d}} A^{S \mathrm{~d}}$ & 0.95 & \\
\hline$S_{\mathrm{d}}$ & where $A$ is area of its catchment $\left(\mathrm{km}^{2}\right)$ & 0.2 & \\
\hline
\end{tabular}

The Maha season (from 1 October to 31 March) between 2010 and 2013 was selected to be the validation period. (The Maha season from October 2013 to March 2014 was excluded from the discussion, because some TRMM and PERSIANN data were not available for this period and also because the dam began operating in July 2013). Mean and maximum figures for the calculated discharges were compared with the corresponding observed values. The difference between the observed and calculated hydrographs was evaluated by calculating the Root Mean Squared Error (RMSE), the Mean Absolute Error (MAE), the Coefficient of Efficiency (CE; [30]), and the Relative Bias (MB), which have widely been used in evaluation of hydrological model (e.g., [31,32]), as per the following equations:

$$
\begin{gathered}
R M S E=\sqrt{\frac{1}{N} \sum_{i=1}^{N}\left(Q_{i}-\hat{Q}_{i}\right)^{2}} \\
M A E=\frac{1}{N} \sum_{i=1}^{N}\left|Q_{i}-\hat{Q}_{i}\right| \\
C E=1-\left(\sum_{i=1}^{N}\left(Q_{i}-\hat{Q}_{i}\right)^{2} / \sum_{i=1}^{N}\left(Q_{i}-Q\right)^{2}\right) \\
R B=\sum_{i=1}^{N}\left(\hat{Q}_{i}-Q_{i}\right) / \sum_{i=1}^{N} Q_{i}
\end{gathered}
$$

where $\hat{Q}_{i}$ is estimated discharge at time $i, Q_{i}$ is discharge observed or calculated with the Gauged-R at time $i, Q$ is average of $Q_{i}$, and $N$ is number of the time series. If Root Mean Squared Error (RMSE) and Mean Absolute Error (MAE) are smaller, the difference can be said to be smaller. Conversely, a larger Coefficient of Efficiency (CE) also equates to a smaller difference. 
In addition, the coincidence of inundation extent, which is also named as "fit" [10] and "correct predictions of flooding" [33], at peak flooding time and during the entire period of a flood event, denoted as $\Phi_{\text {peak }}$ and $\Phi_{\text {total }}$, respectively, was evaluated by the follow equations:

$$
\begin{gathered}
\Phi_{\text {peak }}=\frac{A_{a} \cap A_{b}}{A_{a} \cup A_{b}} \text {, when } A_{a} \cup A_{b} \text { become smaximum } \\
\Phi_{\text {total }}=\left(\sum_{i=1}^{N} A_{a} \cap A_{b} / \sum_{i=1}^{N} A_{a} \cup A_{b}\right)
\end{gathered}
$$

where $A_{a} \cap A_{b}$ is the intersection of these two domains of flood inundation extent, and $A_{a} \cup A_{b}$ is the union of those domains. Here, an estimated depth of more than $0.5 \mathrm{~m}$ is regarded as inundated. These indices are relatively unbiased, since between both underprediction and overprediction they are simply and equitably discriminated so that optimal simulations will provide the best compromise between these two undesirable attributes [33].

\subsection{Correction of SREs by Scale Factors}

The scale factor is relevant to adjust the bias from all the SREs to make them well correlated with the gauged rainfall, prior generating the hydrograph and the inundation extent from flood inundation models. This will also help to improve the accuracy and product comparison with the remote sensing-derived flood extent. Therefore, in this study, scale factors were determined by comparing the gauged data and the SREs from 1 October 2010 to 30 September 2014, and then employing these to correct the discrepancy.

\section{Results}

\subsection{Characteristics of the Satellite Rainfall Estimate Products}

Comparison of yearly total precipitation amounts of the SREs to those of the gauged rainfall are shown in Table 3. In addition, ratios of the accumulated amounts of the SREs from October 2010 to September 2014 to those of the gauged data are shown, as scale factors, in Table 3. All of the yearly amounts of the SREs are smaller than those gauged, hence the scale factors are greater than 1.

Fluctuations in monthly amounts of the SREs are shown in Figure 3, in comparison with those of the gauged data. The fluctuation graphs tend to look similar to each other; this justifies applying the SREs in lieu of observed data.

Comparisons of the monthly total SRE and Gauged-R amounts are shown in Figure 4a, with $\left(R^{2}\right)$ being the coefficients of determination (used to derive proportional relationships). Because this value for TRMM and GSMaP is larger, these SREs are likely to be better correlated than PERSIANN with those of the Gauged-R data. The SRE data corrected using the scale factors (calculated as ratios of the accumulated amounts from October 2010 to September 2014 between Gauged-R and SRE; denoted with a postfix 'SF' hereafter; their values are shown in Table 3) were also tested and are shown in Figure $4 \mathrm{~b}$. In this graph, the $R^{2}$ values for the corrected database are closer to 1 than those of Figure $4 \mathrm{a}$, indicating that correcting the SRE data increased its correlation with the Gauged-R data.

Table 3. Summation of yearly total amount and scale factors of the rainfall datasets.

\begin{tabular}{ccccc}
\hline \multirow{2}{*}{ Datasets } & \multicolumn{2}{c}{ Accumulated Rainfall (Unit in mm) } & \multirow{2}{*}{ Scale Factor } \\
\cline { 2 - 4 } & $\mathbf{2 0 1 1}$ & $\mathbf{2 0 1 2}$ & $\mathbf{2 0 1 3}$ & \\
\hline Gauged-R & 3559 & 2068 & 2164 & - \\
PERSIANN & 2199 & 1643 & 1584 & 1.34 \\
TRMM & 2632 & 1697 & + & 1.23 \\
GSMaP & 2891 & 1802 & 1567 & 1.24 \\
\hline † Tropical Rainfall Measuring Mission (TRMM) data are not available in November
\end{tabular}

and December in 2013. 


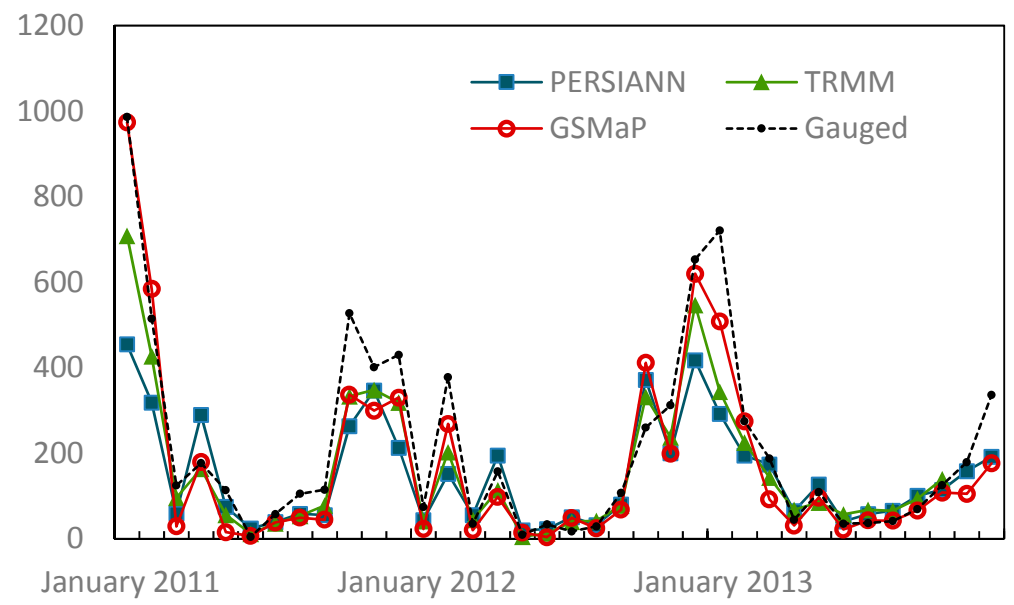

Figure 3. Monthly variation of the SRE values and those of the gauged data.
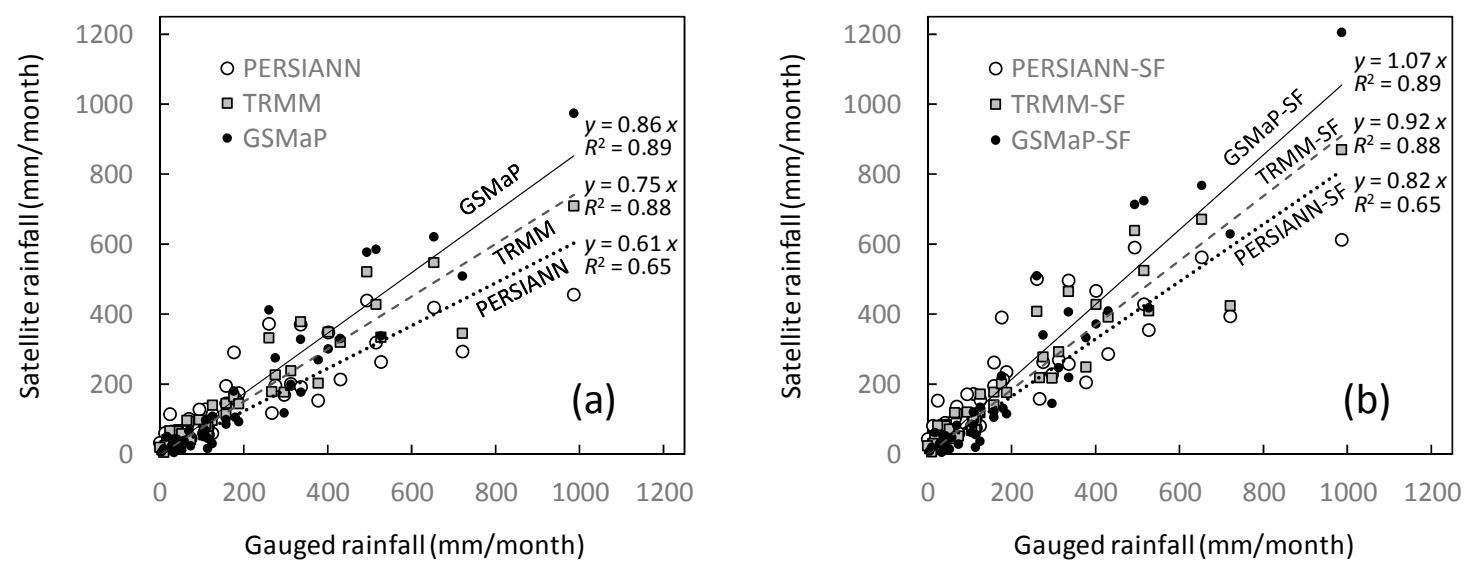

Figure 4. Comparison of monthly rainfall amounts of the SREs to Gauged-R data; (a) raw data; (b) data corrected by the scale factors.

\subsection{Simulated Discharge and Flood Inundation Extent}

\subsubsection{Discharge}

Calibration had been done with the gauged rainfall data for the period from 1 January to 28 February 2011. As a result, the set of parameters with $n_{\mathbf{S}}=0.06, n_{\mathrm{R}}=0.03$, and $k_{\mathrm{a}}=0.1$ were chosen. Details in the parameter determination are described in the authors' previous study [24].

Results of calculating discharge at Tampitiya, using the calibrated RRI model with the SREs, are shown in Figure 5. All of the SREs were suitable for applying to the RRI model.

The results for the 2010-2011 Maha season, including the calibration period (Figure 5(a1)-(a3)), show that the peak discharge calculated with PERSIANN-SF was much smaller than the observed peak and that calculated with Gauged-R data, even though the scale factor was considered. In contrast, the peak discharges simulated with the TRMM-SF and GSMaP-SF data were closer to the observed data and those calculated with the Gauged-R data. This would be because the relationship between PERSIANN and Gauged-R was less linear, indicating that PERSIANN might not be able to accurately illustrate extreme rainfall events. However, the results of another flooding period, during the 2012-2013 Maha season (Figure 5(b1)-(b3)), show that the peak discharge calculated with GSMaP-SF tended to be more overestimated than those generated using PERSIANN-SF and TRMM-SF. In addition, in the hydrographs calculated by all of SREs, there were several large peaks which did not appear in the observed hydrograph, specifically during the Maha season (Figure 5(b1)-(b3)). 

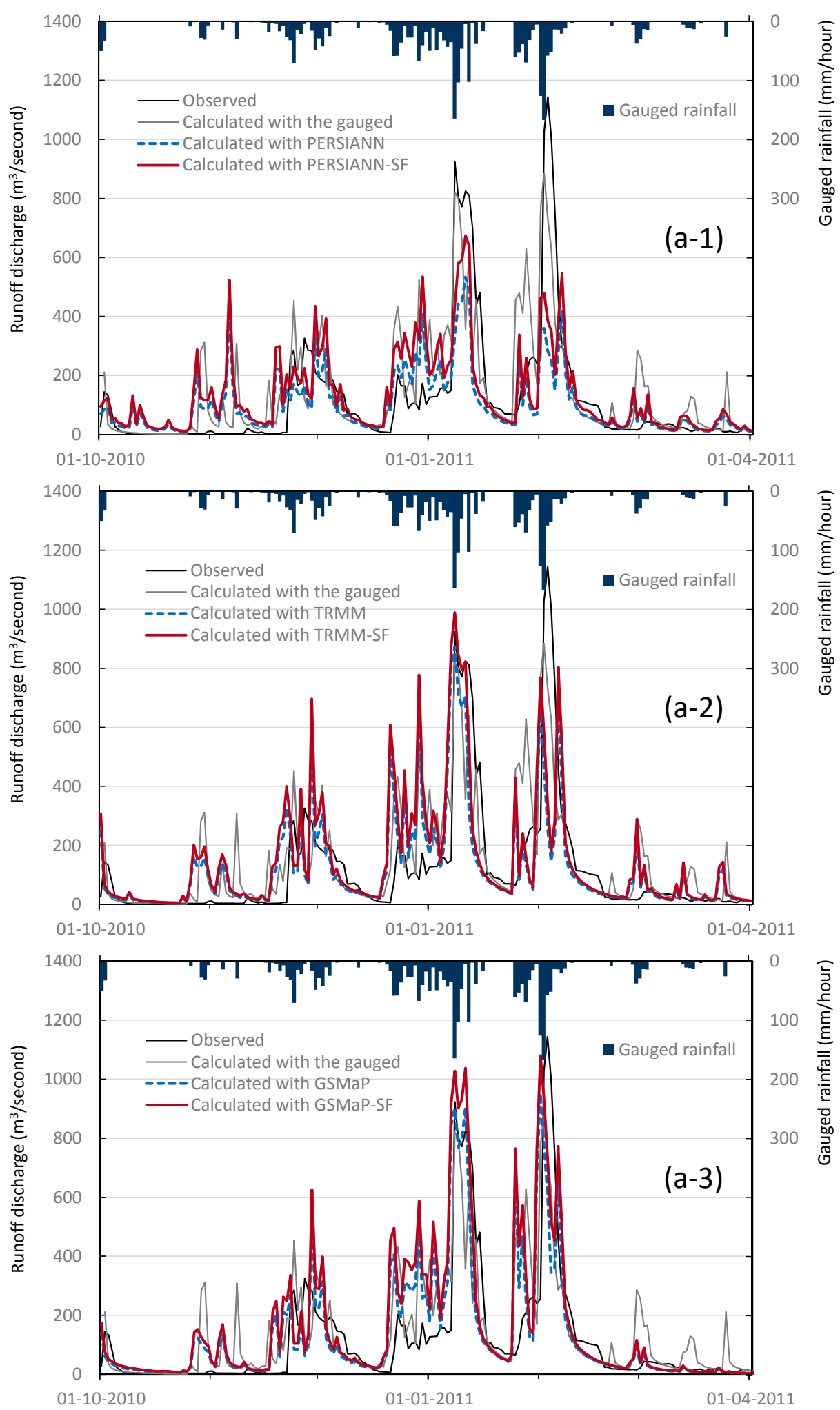

Figure 5. Cont. 

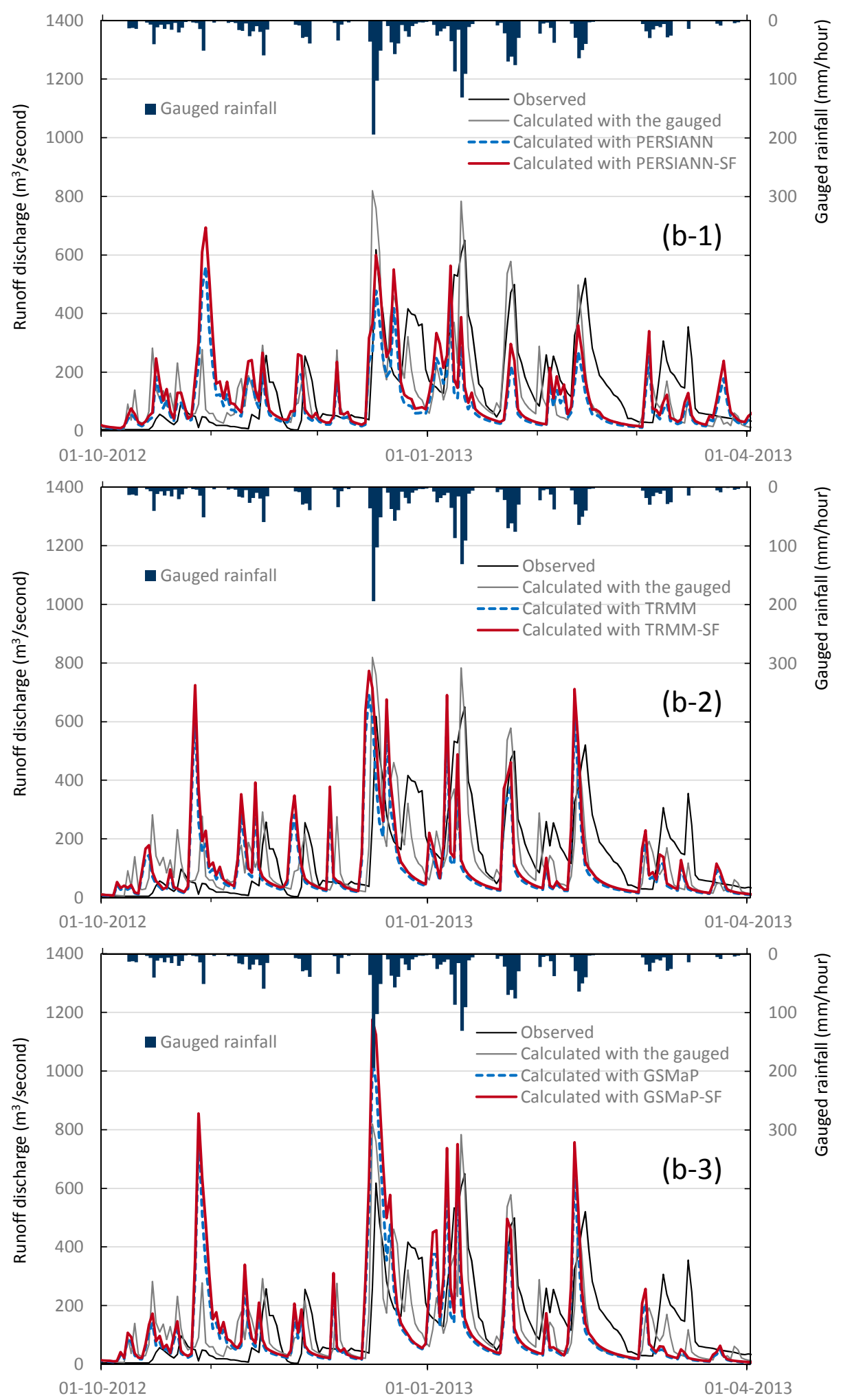

Figure 5. Hydrographs at Tampitiya produced with Gauged-R data and that of the SREs for the calibration period (from October 2010 to March 2011; (a1)-(a3)) and part of the verification period (from October 2012 to March 2013; (b1)-(b3)).

The mean and the maximum of the calculated discharges were compared with those of the observed data (Table 4). The maximum discharge calculated with PERSIANN-SF tended to 
be underestimated in comparison to the observed discharge and that calculated with Gauged- $R$ data; the maximum for the 2010-2011 Maha season was much smaller, just as the peak discharge in the hydrograph appeared much smaller (Figure 5(a1)). The maximum discharges calculated with TRMM-SF and GSMaP-SF for the 2010-2011 Maha season were larger than those calculated with PERSIANN-SF and closer to the observed figures and those calculated with Gauged-R data. However, the maximum discharge calculated with GSMaP data for the 2012-2013 Maha season was highly overestimated against the observed data and that calculated with Gauged-R data, as also observed in the hydrograph (Figure 5(b3)).

Differences among the observed and calculated discharges were evaluated using RMSE, MAE, CE, and RB methods (Tables 5 and 6). The RMSE and MAE values for PERSIANN-SF were smaller than those for TRMM-SF and GSMaP-SF. However, it should be noted that the relative difference was mostly comparable since these values were synchronized with the mean for each of the SREs. For CE, the results with PERSIANN-SF were evaluated as being 'less different' from both those observed and calculated with Gauged-R data. For the rest, especially for the 2010-2011 Maha season, the indicators showed that the hydrograph calculated with GSMaP-SF was 'more similar' to the observed and that calculated with Gauged-R than that calculated with TRMM-SF. The values of RB ranged from -0.194 to 0.134 for comparison of the calculated discharge with Gauged-R data, but there was no obvious tendency among the result.

Table 4. Mean and maximum of the observed and calculated discharge in the Maha seasons.

\begin{tabular}{cccccccccccc}
\hline & \multicolumn{2}{c}{ Observed } & \multicolumn{3}{c}{ Gauged-R } & \multicolumn{2}{c}{ PERSIANN-SF } & \multicolumn{2}{c}{ TRMM-SF } & \multicolumn{2}{c}{ GSMaP-SF } \\
\hline Maha & Mean & Max. & Mean & Max. & Mean & Max. & Mean & Max. & Mean & Max. \\
\hline $2010-2011$ & 121 & 1144 & 147 & 884 & 137 & 674 & 153 & 989 & 167 & 1080 \\
$2011-2012$ & 121 & 675 & 104 & 662 & 84.1 & 597 & 87.9 & 746 & 87.2 & 728 \\
$2012-2013$ & 140 & 650 & 126 & 819 & 123 & 693 & 123 & 773 & 141 & 1176 \\
\hline & \multicolumn{4}{c}{ Unit: $\mathrm{m}^{3} / \mathrm{s}}$.
\end{tabular}

Table 5. Evaluated error of the calculated discharge in the Maha seasons, in comparison with the observed discharge.

\begin{tabular}{ccccccccc}
\hline & \multicolumn{4}{c}{ Gauged-R } & \multicolumn{5}{c}{ PERSIANN-SF } \\
\hline Maha & RMSE & MAE & CE & RB & RMSE & MAE & CE & RB \\
\hline $2010-2011$ & 139 & 83.7 & 0.552 & 0.212 & 154 & 91.7 & 0.449 & 0.128 \\
$2011-2012$ & 145 & 89.0 & -0.031 & -0.135 & 120 & 78.9 & 0.297 & -0.303 \\
$2012-2013$ & 118 & 86.6 & 0.334 & -0.098 & 160 & 113 & -0.219 & -0.120 \\
\hline \multicolumn{4}{c}{ TRMM-SF } & \multicolumn{5}{c}{ GSMaP-SF } \\
\hline Maha & RMSE & MAE & CE & RB & RMSE & MAE & CE & RB \\
\hline $2010-2011$ & 184 & 103 & 0.213 & 0.265 & 171 & 95.1 & 0.321 & 0.375 \\
$2011-2012$ & 152 & 101 & -0.124 & -0.271 & 153 & 96.6 & -0.168 & -0.277 \\
$2012-2013$ & 185 & 127 & -0.638 & -0.122 & 199 & 135 & -0.903 & 0.004 \\
\hline
\end{tabular}

Unit: $\mathrm{m}^{3}$ /second for RMSE and MAE, no dimension for CE and RB.

Table 6. Evaluated error of the calculated discharge in the Maha seasons, in comparison of the calculated discharge with Gauged-R data.

\begin{tabular}{ccccccccccccc}
\hline \multicolumn{4}{c}{ PERSIANN-SF } & \multicolumn{4}{c}{ TRMM-SF } & \multicolumn{4}{c}{ GSMaP-SF } \\
\hline Maha & RMSE & MAE & CE & RB & RMSE & MAE & CE & RB & RMSE & MAE & CE & RB \\
\hline $2010-2011$ & 126 & 78.9 & 0.534 & -0.069 & 144 & 79.7 & 0.396 & 0.043 & 142 & 77.9 & 0.410 & 0.134 \\
$2011-2012$ & 94.9 & 53.6 & 0.459 & -0.194 & 113 & 62.0 & 0.277 & -0.157 & 122 & 64.6 & 0.112 & -0.164 \\
$2012-2013$ & 121 & 70.3 & 0.318 & -0.024 & 160 & 93.8 & -0.196 & -0.026 & 160 & 91.8 & -0.194 & 0.114 \\
\hline
\end{tabular}




\subsubsection{Flood Inundation Extent}

The distribution of maximum flood inundation duration between December 2010 and March 2011 was illustrated using the result of calculation by the calibrated model with the SREs and the gauged data (Figure 6). The extent of inundation duration calculated using TRMM-SF and GSMaP-SF data was a little overestimated but similar to that calculated from the gauged rainfall; that calculated using PERSIANN-SF data was likely underestimated. The distribution of flood inundation depth on the day when the largest flood peak came within this period (3 February 2011) was also illustrated (Figure 7). Underestimation in the calculation using PERSIANN-SF data was consistent with the result that the hydrographs at Tampitiya (Figure 5(a1)) calculated with PERSIANN-SF were smaller than the observed data and those calculated with Gauged-R data during the 2010-2011 Maha season. On the other hand, the distribution of inundation depth calculated using GSMaP-SF data was close to that calculated with Gauged-R data.

The coincidence of flood inundation extent between the SREs and the Gauged-R data, denoted as $\Phi_{\text {peak }}$ and $\Phi_{\text {total }}$, was evaluated (Tables 7 and 8). As with the flood inundation maps (Figure 6), the correspondence of inundation extent calculated using PERSIANN-SF data was less pronounced than that generated using TRMM-SF and GSMaP-SF data, especially for the 2010-2011 Maha season.

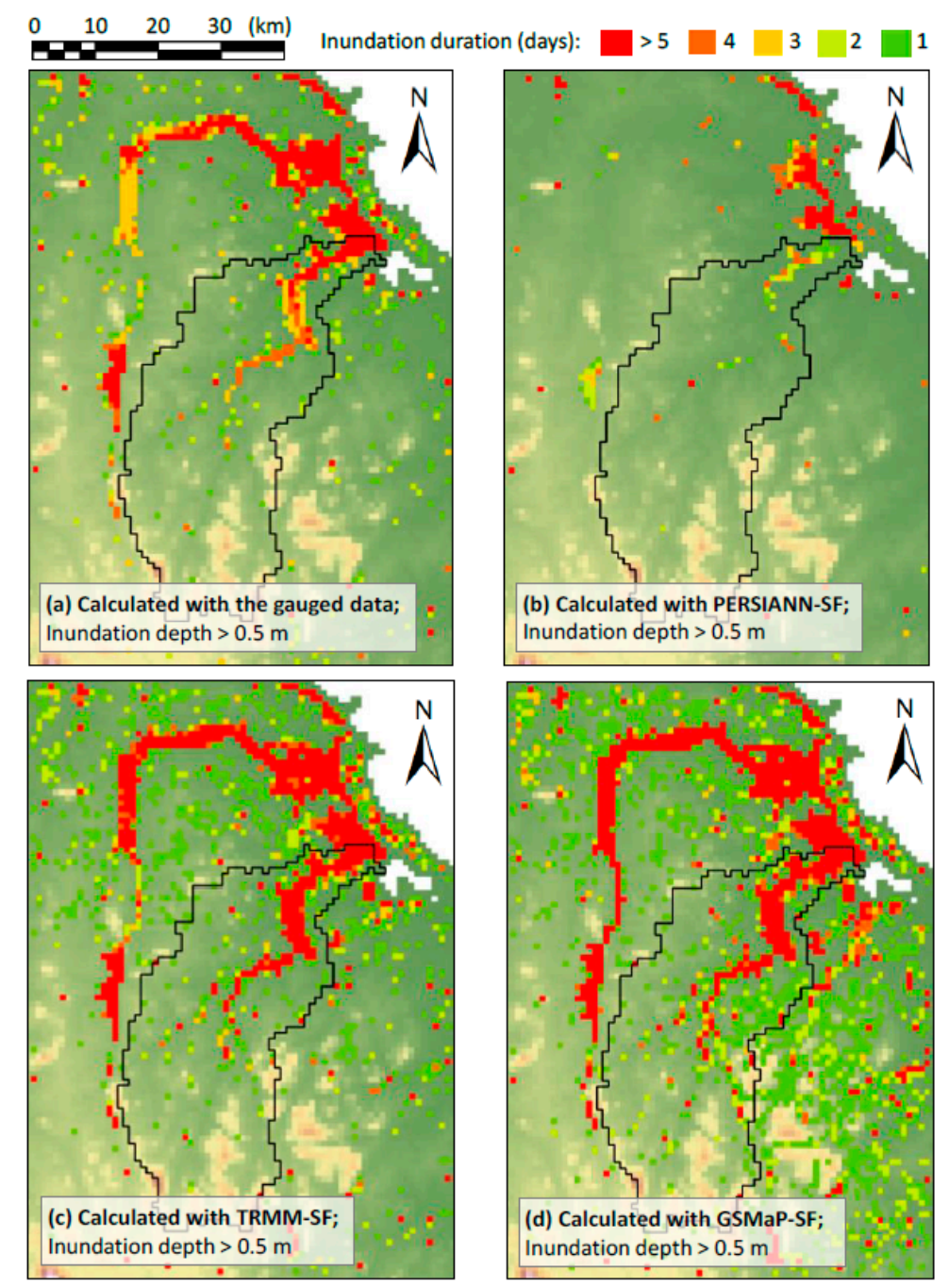

Figure 6. Distribution of maximum flood inundation duration from December 2010 to March 2011, calculated by the calibrated RRI model; (a) Gauged-R; (b) PERSIANN-SF; (c) TRMM-SF; and (d) GSMaP-SF. 

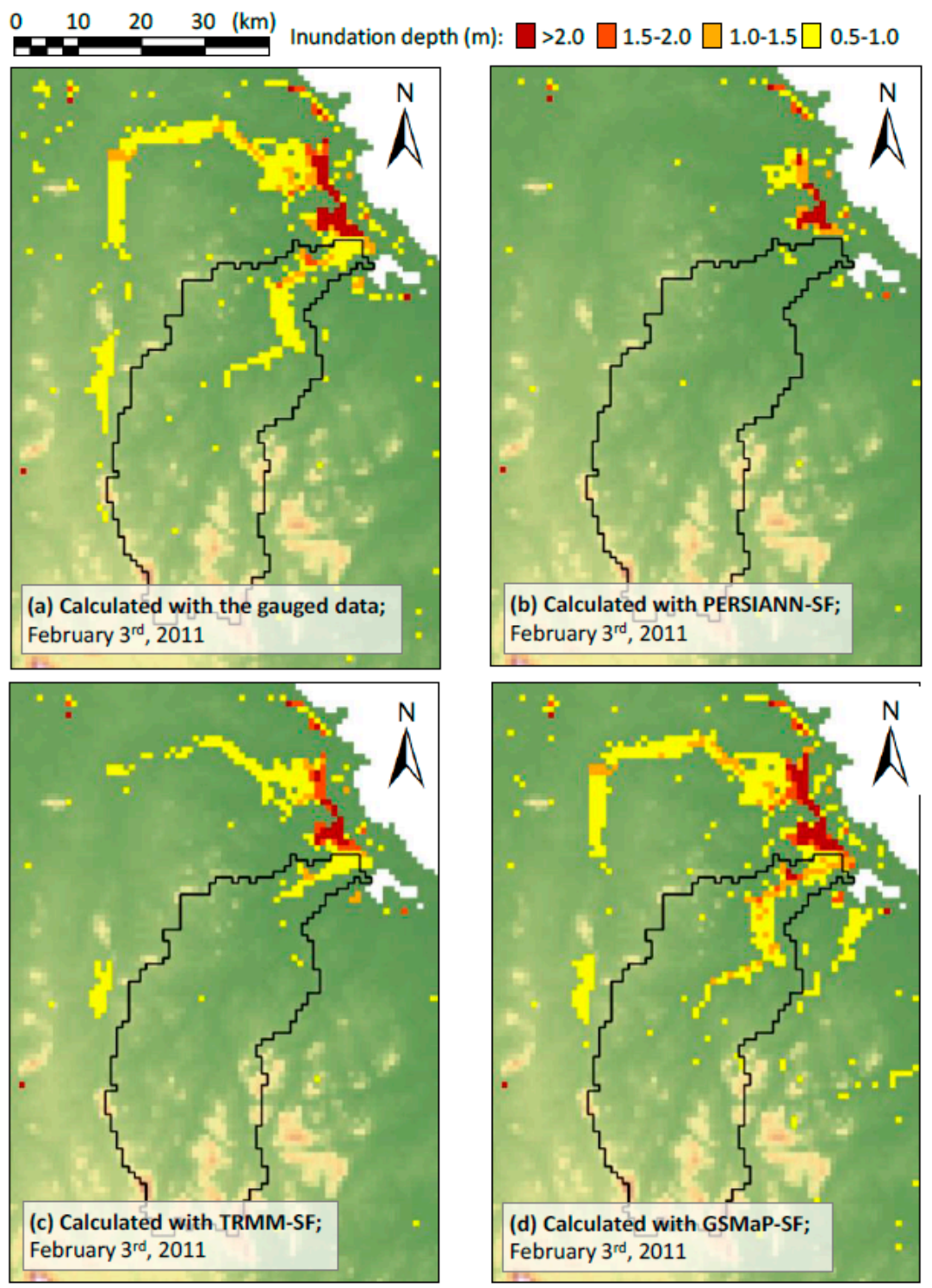

Figure 7. Distribution of flood inundation depth on 3 February 2011, calculated by the calibrated RRI model; (a) Gauged-R; (b) PERSIANN-SF; (c) TRMM-SF; and (d) GSMaP-SF.

Table 7. Coincidence of inundation extent for the peak flooding times and the entire flooding periods. Coincidence ( $\Phi_{\text {peak }}$ and $\Phi_{\text {total }}$ ) was defined by Equations (8) and (9). The larger $\Phi_{\text {peak }}$ and $\Phi_{\text {total }}$ are more related to the flood inundation extent between the SREs and the Gauged-R data.

\begin{tabular}{lllllll}
\hline & \multicolumn{2}{c}{ PERSIANN-SF } & \multicolumn{2}{c}{ TRMM-SF } & \multicolumn{2}{c}{ GSMaP-SF } \\
\hline & $\Phi_{\text {peak }}$ & $\Phi_{\text {total }}$ & $\Phi_{\text {peak }}$ & $\Phi_{\text {total }}$ & $\Phi_{\text {peak }}$ & $\Phi_{\text {total }}$ \\
\hline Maha 2010-2011 & 0.160 & 0.484 & 0.438 & 0.549 & 0.451 & 0.521 \\
Maha 2011-2012 & 0.477 & 0.682 & 0.435 & 0.698 & 0.412 & 0.691 \\
Maha 2012-2013 & 0.077 & 0.487 & 0.105 & 0.526 & 0.355 & 0.472 \\
\hline
\end{tabular}

Unit: no dimension. 
Table 8. Coincidence of inundation extent for the peak flooding times and the entire flooding periods. Values of the intersection $\left(A_{\mathrm{a}} \cap A_{\mathrm{b}}\right)$ and the union $\left(A_{\mathrm{a}} \cup A_{\mathrm{b}}\right)$ of domains of flood inundation were calculated by the SREs and Gauged-R and their rate $(\Phi)$ for peak flooding times in the Maha 2010-2011 season.

\begin{tabular}{ccccccccccc}
\hline \multirow{2}{*}{ Specific Date } & \multicolumn{3}{c}{ PERSIANN-SF } & \multicolumn{3}{c}{ TRMM-SF } & \multicolumn{3}{c}{ GSMaP-SF } \\
\cline { 2 - 10 } & $A_{\mathbf{a}} \cap A_{\mathbf{b}}$ & $A_{\mathbf{a}} \cup A_{\mathbf{b}}$ & $\Phi$ & $A_{\mathbf{a}} \cap A_{\mathbf{b}}$ & $A_{\mathbf{a}} \cup A_{\mathbf{b}}$ & $\Phi$ & $A_{\mathbf{a}} \cap A_{\mathbf{b}}$ & $A_{\mathbf{a}} \cup A_{\mathbf{b}}$ & $\Phi$ \\
\hline 8 January 2011 & 254 & 617 & 0.412 & 616 & 1405 & 0.438 & 615 & 1428 & 0.431 \\
11 January 2011 & 402 & 705 & 0.570 & 610 & 864 & 0.706 & 696 & 1457 & 0.478 \\
1 February 2011 & 120 & 749 & 0.160 & 424 & 749 & 0.566 & 741 & 1643 & 0.451 \\
\hline
\end{tabular}

Unit: $\mathrm{m}^{3} /$ second for $A_{\mathrm{a}} \cap A_{\mathrm{b}}$ and $A_{\mathrm{a}} \cup A_{\mathrm{b}}$, no dimension for $\Phi$.

\section{Discussion}

The simulations made by applying the SREs generally produced satisfactory results; in fact, they are closely related (Tables 5 and 6 ), although there were mismatches in discharge caused by the differences between the precipitation amount of the SREs and the gauged data. Regarding the similarity of hydrographs evaluated using CE methods, PERSIANN-SF derived better estimates of discharge than TRMM-SF and GSMaP-SF (Tables 5 and 6). However, especially for the 2010-2011 Maha season when the large flooding event occurred, the flood inundation extent maps calculated using TRMM-SF and GSMaP-SF data were 'more similar' to those calculated with Gauged-R data, while the flood inundation extent calculated with PERSIANN-SF was less than that with the Gauged-R data (Figure 6; Tables 7 and 8). Comparing the results from using TRMM-SF and GSMaP-SF data, the application with GSMaP-SF gave stably higher scores of $\Phi_{\text {peak }}$ and $\Phi_{\text {total }}$, while $\Phi_{\text {peak }}$ of using TRMM-SF during the 2012-2013 Maha seasons appeared as the relatively small value (Table 7). In addition, those calculated with GSMaP-SF tended to overestimate while those with TRMM-SF were likely underestimating (Figure 6), although the coincidence scores were not significantly different (Table 8). From this it can be said that calculation with GSMaP-SF would be on the safe side regarding application to flood early warning practices. Considering these results, and focusing on the ability to simulate flood extent, using GSMaP-SF data was the most appropriate choice for executing the model.

Correspondence of SREs to ground-observation rainfall data has been studied in various regions of the world. Some of them reported that GSMaP had larger bias against ground-observation [34-36]. However, even if bias of SREs was considerable, total amount of rainfall could be somewhat corrected by multiplying the scale factor, as shown in this study. There are limitations to applying scale factor to improve the bias in areas where gauged data is absent. In this study, the bias correction was applied for the catchment area with the dependency of gauged data. For ungauged areas, however, use of multisource SREs would be another possibility of the bias correction, and monthly- and seasonal-basis scale factors can also be employed for the bias adjustment. There have been several studies to apply and evaluate some advanced methods which enable bias correction of SREs, even in sparsely gauged areas [37,38]. At the same time, dependence of SREs on topography, season, and other factors are being studied for bias correction $[39,40]$. It would be a future task to sophisticate the bias correction based on this knowledge for improved simulation in ungauged areas. Furthermore, as the previous study mentioned that SREs with higher spatial resolution enable their application on a more local scale [36], the better result by using GSMaP-SF would possibly be due to its finer grid size. It should also be noted that algorithms generating SRE products, including GSMaP, are still being developed, which keeps improving their performance. Hence, it would be recommended to test the applicability of each of the SREs and correction methods according to the procedures like the way shown in this study.

\section{Conclusions}

Three datasets of SREs (PERSIANN, TRMM, and GSMaP) were applied to the RRI model and their ability to simulate flood inundation tested for a basin in eastern Sri Lanka. In summary, the findings of this study are that: 
- All of the SREs could be applied to simulate flood inundation using the RRI model, to obtain hydrographs and flood inundation maps.

- The amount of precipitation of the SREs tended to be larger than that of the gauged data, but correcting this discrepancy with a scale factor (SF) improved the simulations.

- The error evaluation of hydrographs and the coincidence evaluation of inundation extent for each of the SREs gave conflicting results: the former gave the better score to the results produced using PERSIANN-SF data, while the latter evaluated those produced using GSMaP-SF data as the best. From the point of view of simulating the flood inundation extent, using GSMaP-SF seemed more appropriate for executing the model.

- The better performance by using GSMaP-SF would possibly be due to its finer resolution. Because algorithms generating SRE products are still being improved and corrections such as multiplying a scale factor are also applicable, it would be recommended to test the applicability of each of the SREs and correction methods according to the procedures shown in this study.

These findings indicate that the procedures shown in this study could support decision makers to issue early flood warnings and quickly predict flood situations, especially in areas where in-situ observations are limited or poorly equipped.

Acknowledgments: A part of this study was funded by the Ministry of Agriculture, Forestry, and Fisheries (MAFF), Japan; the CGIAR Research Program on Climate Change, Agriculture, and Food Security (CCAFS), Water, Land, and Ecosystems (WLE); and the International Water Management Institute (IWMI). We would like to thank the Department of Irrigation in Sri Lanka, the Survey Department of Sri Lanka, the Department of Meteorology in Sri Lanka, and the Japan Aerospace Exploration Agency (JAXA) for sharing their data and giving kind advice. The authors are indebted to three anonymous reviewers and editors of the special issues for their constructive comments and suggestions.

Author Contributions: S.Y. and G.A. performed the modeling and the analyses; S.Y. wrote the paper.

Conflicts of Interest: The authors declare no conflict of interest.

\section{References}

1. EM-DAT: The CRED/OFDA International Disaster Database. Available online: http://www.emdat.be/ (accessed on 15 January 2016).

2. Sorooshian, S.; Hsu, K.L.; Gao, X.; Gupta, H.V.; Imam, B.; Braithwaite, D. Evaluation of PERSIANN system satellite-based estimates of tropical rainfall. Bull. Am. Meteorol. Soc. 2000, 81, 2035-2046. [CrossRef]

3. TRMM. Available online: http:/ / trmm.gsfc.nasa.gov/ (accessed on 13 September 2016).

4. JAXA Global Rainfall Watch. Available online: http://sharaku.eorc.jaxa.jp/GSMaP/ (accessed on 13 September 2016).

5. Nikolopoulos, E.I.; Anagnostou, E.N.; Borga, M. Using high-resolution satellite rainfall products to simulate a major flash flood event in Northern Italy. J. Hydrometeorol. 2013, 14, 171-185. [CrossRef]

6. Meng, J.; Li, L.; Hao, Z.; Wang, J.; Shao, Q. Suitability of TRMM satellite rainfall in driving a distributed hydrological model in the source region of Yellow River. J. Hydrol. 2014, 509, 320-332. [CrossRef]

7. Casse, C.; Gosset, M.; Peugeotb, C.; Pedinottic, V.; Boonec, A.; Tanimound, B.A.; Decharmec, B. Potential of satellite rainfall products to predict Niger River flood events in Niamey. Atmos. Res. 2015, 163, 162-176. [CrossRef]

8. Nguyen, P.; Thorstensen, A.; Sorooshian, S.; Hsu, K.; AghaKouchak, A. Flood forecasting and inundation mapping using HiResFlood-UCI and near-real-time satellite precipitation data: The 2008 Iowa Flood. J. Hydrometeorol. 2015, 16, 1171-1183. [CrossRef]

9. Nanda, T.; Sahoob, B.; Beriaa, H.; Chatterjee, C. A wavelet-based non-linear autoregressive with exogenous inputs (WNARX) dynamic neural network model for real-time flood forecasting using satellite-based rainfall products. J. Hydrol. 2016, 539, 57-73. [CrossRef]

10. Bates, P.D.; De Roo, A.P.J. A simple raster based model for flood inundation simulation. J. Hydrol. 2000, 236, 54-77. [CrossRef]

11. Hydrologic Engineering Center. Hydrologic Modeling System: Technical Reference Manual; US Army Corps of Engineers Hydrologic Engineering Center: Davis, CA, USA, 2000. 
12. Hydrologic Engineering Center. River Analysis System: Hydraulic Reference Manual; US Army Corps of Engineers Hydrologic Engineering Center: Davis, CA, USA, 2002.

13. Rainfall-Runoff-Inundation (RRI) Model. Available online: http://www.icharm.pwri.go.jp/research/rri/ rri_top.html (access on 26 September 2017).

14. Bitew, M.M.; Gebremichael, M. Assessment of satellite rainfall products for streamflow simulation in medium watersheds of the Ethiopian highlands. Hydrol. Earth Syst. Sci. 2011, 15, 1147-1155. [CrossRef]

15. Bitew, M.M.; Gebremichael, M. Evaluation of satellite rainfall products through hydrologic simulation in a fully distributed hydrologic model. Water Resour. Res. 2011, 47, W06526. [CrossRef]

16. Liu, X.; Yang, T.; Hsu, K.; Liu, C.; Sorooshian, S. Evaluating the streamflow simulation capability of PERSIANN-CDR daily rainfall products in two river basins on the Tibetan Plateau. Hydrol. Earth Syst. Sci. 2017, 21, 169-181. [CrossRef]

17. Thom, V.; Khoi, D.; Linh, D. Using gridded rainfall products in simulating streamflow in a tropical catchmentA case study of the Srepok River Catchment, Vietnam. J. Hydrol. Hydromech. 2016, 65, 18-25. [CrossRef]

18. Alazzy, A.A.; Lü, H.; Chen, R.; Ali, A.B.; Zhu, Y.; Su, L. Evaluation of satellite precipitation products and their potential influence on hydrological modeling over the Ganzi River Basin of the Tibetan Plateau. Adv. Meteorol. 2017, 2017. [CrossRef]

19. Schumann, G.J.-P.; Neal, J.C.; Voisin, N.; Andreadis, K.M.; Pappenberger, F.; Phanthuwongpakdee, N.; Hall, A.C.; Bates, P.D. A first large scale flood inundation forecasting model. Water Resour. Res. 2013, 49, 6248-6257. [CrossRef]

20. Ushiyama, T.; Sayama, T.; Tatebe, Y.; Fujioka, S.; Fukami, K. Numerical simulation of 2010 Pakistan Flood in the Kabul River Basin by using lagged ensemble rainfall forecasting. J. Hydrometeorol. 2014, 15, 193-211. [CrossRef]

21. Katiraie-Boroujerdy, P.-S.; Asanjan, A.A.; Hsu, K.-L.; Sorooshian, S. Intercomparison of PERSIANN-CDR and TRMM-3B42V7 precipitation estimates at monthly and daily time scales. Atmos. Res. 2017, 193, 36-49. [CrossRef]

22. Tan, M.L.; Gassman, P.W.; Cracknell, A.P. Assessment of three long-term gridded climate products for hydro-climatic simulations in Tropical River Basins. Water 2017, 9, 229. [CrossRef]

23. Serrat-Capdevila, A.; Merino, M.; Valdes, J.B.; Durcik, M. Evaluation of the performance of three satellite precipitation products over Africa. Remote Sens. 2016, 8, 836. [CrossRef]

24. Yoshimoto, S.; Amarnath, G. Application of a flood-inundation model to analyze the potential impacts of a flood-control plan in Mundeni Aru river basin, Sri Lanka. Nat. Hazards 2017. under review.

25. Rambukkan Oya. Available online: http://www.irrigation.gov.lk/index.php?option=com_content\&view= article\&id=375\%3Arambukkan-oya\&catid=130\%3Amajor-projects\&lang=en (accessed on 27 March 2016).

26. Amarnath, G.; Umer, Y.M.; Alahacoon, N.; Inada, Y. Modelling the flood-risk extent using LISFLOOD-FP in a complex watershed: Case study of Mundeni Aru River Basin, Sri Lanka. Proc. IAHS 2015, 370, 131-138. [CrossRef]

27. Hsu, K.; Gao, X.; Sorooshian, S.; Gupta, H.V. Precipitation estimation from remotely sensed information using artificial neural networks. J. Appl. Meteorol. 1997, 36, 1176-1190. [CrossRef]

28. Kummerow, C.; Simpson, J.; Thiele, O.; Barnes, W.; Chang, A.T.; Stocker, E.; Adler, R.F.; Hou, A.; Kakar, R.; Wentz, F; et al. The status of the Tropical Rainfall Measuring Mission (TRMM) after two years in orbit. J. Appl. Meteorol. 2000, 39, 1965-1982. [CrossRef]

29. Lehner, B.; Verdin, K.; Jarvis, A. New global hydrography derived from spaceborne elevation data. Eos Trans. Am. Geophys. Union 2008, 89, 93-94. [CrossRef]

30. Nash, J.E.; Sutcliffe, J.V. River flow forecasting through conceptual models, 1. A discussion of principles. J. Hydrol. 1970, 10, 282-290. [CrossRef]

31. Dawson, C.W.; Abrahart, R.J.; Shamseldin, A.Y.; Wilby, R.L. Flood estimation at ungauged sites using artificial neural networks. J. Hydrol. 2006, 319, 391-409. [CrossRef]

32. Chiang, Y.-M.; Hsu, K.-L.; Chang, F.-J.; Hong, Y.; Sorooshian, S. Merging multiple precipitation sources for flash flood forecasting. J. Hydrol. 2007, 340, 183-196. [CrossRef]

33. Schumann, G.; Bates, P.D.; Horritt, M.S.; Matgen, P.; Pappenberger, F. Progress in integration of remote sensing-Derived flood extent and stage data and hydraulic models. Rev. Geophys. 2009, 47, RG4001.

34. Awange, J.L.; Ferreira, V.G.; Forootan, E.; Khandu; Andam-Akorful, S.A.; Agutu, N.O.; He, X.F. Uncertainties in remotely sensed precipitation data over Africa. Int. J. Climatol. 2016, 36, 303-323. [CrossRef] 
35. Krakauer, N.Y.; Pradhanang, S.M.; Lakhankar, T.; Jha, A.K. Evaluating satellite products for precipitation estimation in mountain regions: A case study for Nepal. Remote Sens. 2013, 5, 4107-4123. [CrossRef]

36. Satgé, F.; Xavier, A.; Pillco Zolá, R.; Hussain, Y.; Timouk, F.; Garnier, J.; Bonnet, M.-P. Comparative assessments of the latest GPM mission's spatially enhanced satellite rainfall products over the main Bolivian watersheds. Remote Sens. 2017, 9, 369. [CrossRef]

37. Müller, M.F.; Thompson, S.E. Bias adjustment of satellite rainfall data through stochastic modeling: Methods development and application to Nepal. Adv. Water Resour. 2013, 60, 121-134. [CrossRef]

38. Habib, E.; Haile, A.T.; Sazib, N.; Zhang, Y.; Rientjes, T. Effect of bias correction of satellite-rainfall estimates on runoff simulations at the source of the Upper Blue Nile. Remote Sens. 2014, 6, 6688-6708. [CrossRef]

39. Gebregiorgis, A.S.; Hossain, F. Understanding the dependence of satellite rainfall uncertainty on topography and climate for hydrologic model simulation. IEEE Trans. Geosci. Remote Sens. 2013, 51, 704-718. [CrossRef]

40. Abebe, S.; Gebregiorgis, F.H. How well can we estimate error variance of satellite precipitation data around the world? Atmos. Res. 2015, 154, 39-59.

(C) 2017 by the authors. Licensee MDPI, Basel, Switzerland. This article is an open access article distributed under the terms and conditions of the Creative Commons Attribution (CC BY) license (http:/ / creativecommons.org/licenses/by/4.0/). 